Alexandre G Torres

Nádia M F Trugo

\section{Evidence of inadequate docosahexaenoic acid status in Brazilian pregnant and lactating women}

\author{
Evidência de estado inadequado \\ do ácido docosahexaenóico em \\ gestantes e nutrizes brasileiras
}

\begin{abstract}
Recently published data concerning dietary intake of fat and food sources of (n-3) long-chain polyunsaturated fatty acids (LCPUFA) in Brazil are reviewed together with data on biochemical indices of PUFA status during pregnancy and lactation and PUFA composition of breast milk in Brazilian adolescents and adults. Potential inadequacies of docosahexaenoic acid (DHA) status among Brazilian pregnant and lactating women have not yet been thoroughly evaluated. The data reviewed show that dietary intake of food sources of n-3 LCPUFA is low and possibly deficient in Brazil, and that biochemical indices of maternal DHA status and breast milk DHA content are low compared to the international literature. These data indicate inadequate DHA status among Brazilian women during pregnancy and lactation, but this evidence needs confirmation through comprehensive and specific population-based studies.
\end{abstract}

DESCRIPTORS: Lactation. Dietary Fats. Fats, Unsaturated. Fatty Acids. Food Consumption. Periodicals as Topic. Pregnancy.
Laboratório de Bioquímica Nutricional e de Alimentos. Instituto de Química. Universidade Federal do Rio de Janeiro. Rio de Janeiro, RJ, Brasil

\section{Correspondence:}

Alexandre G. Torres

Laboratório de Bioquímica Nutricional e de Alimentos

Instituto de Química - Universidade Federal do Rio de Janeiro

Av. Athos da Silveira Ramos, no 149 - Cidade Universitária

CT/ BI. A - Lab. 528A

21941-909 Rio de Janeiro, RJ, Brasil

E-mail: torres@iq.ufrj.br 


\section{RESUMO}

São revistas informações publicadas recentemente sobre a ingestão de tipos de gorduras alimentícias e fontes alimentares de ácidos graxos poli-insaturados de cadeia longa (AGPI-CL) n-3 no Brasil, juntamente com índices bioquímicos do estado nutricional para AGPI em gestantes e nutrizes e a composição em AGPI no leite de mulheres brasileiras adultas e adolescentes. Possíveis inadequações do estado nutricional do ácido docosahexaenóico (DHA) nas gestantes e nutrizes brasileiras ainda não foram investigadas com abrangência e profundidade suficientes no Brasil. Os dados considerados mostram que a ingestão dietética de fontes alimentares de AGPI-CL n-3 no Brasil é baixa e insuficiente. Além disso, os índices bioquímicos do estado nutricional materno para o DHA e o teor de DHA no leite de mulheres brasileiras adultas e adolescentes são baixos, quando comparados com dados internacionais. Estes dados indicam possível estado inadequado para o DHA em gestantes e nutrizes brasileiras, mas estas evidências merecem confirmação por meio de estudos populacionais abrangentes e específicos.

DESCRITORES: Lactação. Gorduras na Dieta. Gorduras Insaturadas. Ácidos Graxos. Consumo de Alimentos. Publicações Periódicas como Assunto. Gestação.

\section{INTRODUCTION}

The status of polyunsaturated fatty acids (PUFA) of $n-6$ and $n-3$ series depends mainly on habitual intake of dietary sources of these fatty acids, both quantitatively and qualitatively. Total intake of $n-3$ and $n-6$ PUFA is a major determinant of nutritional status, but the contribution of individual fatty acids to total intake also affects PUFA status since differences in chain length and position and number of double bonds in the fatty acid structure will result in different biological functions and metabolic use. Furthermore, PUFA status is affected by the ratio of $n-6$ to $n-3$ fatty acids of the habitual diet due to metabolic competition between them and may also be determined by dietary intake of energy, total fats and antioxidants.

During periods of high nutritional demands, such as pregnancy and lactation, energy and nutrient requirements are elevated because of increased needs for the growing tissues of the placenta and fetus and for milk production, respectively. Therefore, these periods are characterized by increased nutritional risks for the mother and the growing fetus or infant. Essential $n-3$ and $n-6$ PUFA, $\alpha$-linolenic (18:3n-3) and linoleic (18:2n-6) acids, especially their very long-chain derivatives (LCPUFA), such as eicosapentaenoic (EPA; 20:5n-3), docosahexaenoic (DHA; 22:6n-3) and arachidonic (AA; 20:4n-6) acids, are required for infant growth, neurodevelopment, and visual function. ${ }^{17}$ The conversion of essential fatty acids to their longer chain polyunsaturated derivatives in humans is limited and insufficient to maintain adequate LCPUFA status, ${ }^{7}$ and consequently maternal dietary intake of preformed LCPUFA must meet the increased requirements. Since placental transfer during pregnancy and breast milk during lactation are practically the only significant sources of $n-3$ and $n-6$ PUFA to growing fetuses and breastfed infants, maternal PUFA status will determine infant status.

Despite the relevance of $n-3$ LCPUFA for maternal health and infant development, studies concerning $n-3$ LCPUFA maternal status and its association with the habitual maternal diet are scarce in Brazil. A search for scientific papers presenting Brazilian data on this subject was carried out in the ISI Web of Knowledge ${ }^{\mathrm{SM}}$ and showed that between 2000 and 2007 there were only a few studies with small groups of pregnant and lactating women. The criteria for search and selection of published data are presented in the respective sections of this paper.

The selected papers describe dietary intake of fat and food sources of $n$-3 LCPUFA in Brazil, together with data on biochemical indices of PUFA status during pregnancy and lactation and PUFA composition of breast milk in Brazilian adolescents and adults. These recent data suggest sub-optimal $n-3$ LCPUFA status among Brazilian pregnant and lactating women. The present paper describes this current evidence and draws attention to potential inadequate DHA status among childbearing women especially regarding DHA status during pregnancy and lactation. 


\section{PATTERN OF INTAKE OF PUFA FOOD SOURCES IN BRAZILIAN PREGNANT AND LACTATING WOMEN}

The current Dietary Reference Intakes (DRI) ${ }^{30}$ for PUFA are based on median intake (Adequate Intake; AI) ${ }^{30}$ of $n-6$ and $n-3$ fatty acids of healthy North American subgroups. The AI of $n-6$ fatty acids is $13 \mathrm{~g} /$ day for pregnant and lactating women, which corresponds to Acceptable Macronutrient Distribution Range (AMDR) of $5 \%$ to $10 \%$ of total energy intake irrespective of age..$^{30}$ The AI of $n-3$ fatty acids is also the same for all age groups and is $1.4 \mathrm{~g} /$ day for pregnant and $1.3 \mathrm{~g} /$ day for lactating women, corresponding to an AMDR of 0.61.2. The intake of $n-6$ and $n-3$ LCPUFA in the general population, including pregnant and lactating women, should correspond to $10 \%$ of these recommendations, respectively. However, a recent consensus on fat intake during pregnancy and lactation ${ }^{22}$ is that pregnant and lactating women should have average intake of at least $0.2 \mathrm{~g} \mathrm{DHA} /$ day, which is above the AI for total $n-3$ LCPUFA. ${ }^{30}$ Maternal DHA intake at this level is associated with beneficial effects on the development of visual acuity, cognitive functions and attention, among other neural-associated functions in infants, ${ }^{20,39}$ and could be achieved with one to two servings of sea fish weekly including oily fish..$^{22}$ Nonetheless, the conversion of recommended amounts of $n-3$ LCPUFA into dietary guidelines depends on food composition data, therefore regional differences regarding servings of fish to be consumed to achieve the recommended intake of $n-3$ LCPUFA are likely to occur.

In order to retrieve references of published papers on fatty acid intake and consumption of food sources of $n-3$ LCPUFA in Brazil, a search on the ISI Web of Knowledge $^{\mathrm{SM}}$ (Web of Science; Current Contents Connect; ISI Proceedings; Biological Abstracts; BIOSIS Previews; CAB Abstracts; Food Science and Technology Abstracts; MEDLINE) was conducted using the keywords "food consumption AND fat AND Brazil*". Eighty-two references were retrieved, but only ten were published between 2000 and 2007, reflecting the current situation of food intake in Brazil and its relevance to the subject. Of them, only one study ${ }^{23}$ presented data on general Brazilian population, and none showed data specifically on fatty acid intake. Data on consumption of food sources of fatty acids in pregnant and lactating women in Brazil were also searched in the same database and the papers relevant to the subject were considered. ${ }^{2,3,8,10,28,33,36,37}$

A recent analysis of data on household food availability in Brazil showed that the relative contribution of fish to total energy consumption is low, being about ten times lower than beef in urban areas, and presents a declining trend $(-50 \%)$ in the last thirty years. ${ }^{23}$ It could be expected that the Brazilian general population, and pregnant and lactating women in particular, are far from achieving the current recommendations for DHA intake. DHA contents ( $\mathrm{g} / 100 \mathrm{~g}$ of food) of the most consumed fish species in southeast Brazil were the following: ${ }^{\mathrm{a}}$ "pescada" (Macrodon oncylodon; fried fish fillet), 0.12; "pescada branca" (Cynoscion spp., fried), 0.45; sardine (Sardinella brasiliensis; fried), 0.36; sardine (Sardinella brasiliensis; canned in oil), 0.46; "corvina" (Micropogonias furnieri; baked), 0.05; and shark (Carcharhinus spp.; stewed), 0.12. Therefore, to achieve the aim of $1.4 \mathrm{~g} \mathrm{DHA} /$ week, two servings of $150 \mathrm{~g}$ of sardines or "pescada branca" should be enough.

However, a larger number of servings and/or serving size are necessary when fish species with lower DHA contents are the main source of this fatty acid in the habitual diet. In the event when higher amounts of fish are needed, the risk of excessive intake of water contaminants should be considered, especially mercury and dioxins. To avoid mercury toxicity, which might counterbalance the beneficial effects of $n-3$ LCPUFA, the intake of predator fish (such as tuna, swordfish, and shark) should be limited to one serving per week. ${ }^{22}$ Therefore, good food sources of DHA should contain high $n-3$ LCPUFA and limited content of water contaminants.

Fish farming is an alternative for increasing DHA contents of this foodstuff and dietary DHA intake, without increasing exposure to water contaminants. In Brazil, fish farming of commercial species has been developed and efforts to improve LCPUFA contents in freshwater fish, such as "surubim" (Pseudoplatystoma coruscans), through diet manipulation has been successful and increased DHA contents up to approximately $0.6 \mathrm{~g} / 100 \mathrm{~g}$ of fish. ${ }^{25}$

Another factor that might limit the adequacy of DHA status in the Brazilian population is the predominance of vegetable oils, especially soybean oil ${ }^{23}$ as dietary source of PUFA. Vegetable oils are rich in essential fatty acids, linoleic and $\alpha$-linolenic acids, but poor in LCPUFA. Linoleic and $\alpha$-linolenic acids are converted into AA and EPA and DHA, respectively, but there is evidence that endogenous DHA synthesis is insufficient, and intake of preformed DHA is advisable. ${ }^{7}$ Furthermore, endogenous conversion of $\alpha$-linolenic acid into EPA and DHA may be hindered by high intake of $n-6$ PUFA. The combination of high consumption of food sources of $n-6$ PUFA and low consumption of $n-3$ PUFA, especially DHA, would result in a high $n-6 / n-3$ ratio in the diet, putting Brazilian population at risk of inadequate DHA status.

a Universidade Estadual de Campinas. Núcleo de Estudos e Pesquisas em Alimentação. Tabela brasileira de composição de alimentos - TACO, versão 2. Campinas; 2006. [Internet] [cited 2007 Dec 9]. Available from: http://www.unicamp.br/nepa/taco/contar/taco_versao2.pdf] 
Detailed data on fatty acid intake of Brazilian pregnant and lactating women are scarce, especially from large population-based studies. Few studies have been carried out with a limited number of women in different Brazilian cities, such as Rio de Janeiro, ${ }^{3,8,28,33,37}$ Brasília $^{10}$ and Viçosa $^{36}$ and they suggest inadequate intake of $n-3$ PUFA during the reproductive cycle. The pattern of dietary intake of fat sources in Brazilian adult women during pregnancy and lactation shows a predominant intake of food sources of essential fatty acids and n-6 LCPUFA, such as vegetable oils, mainly soybean oil, and meat, over food sources of preformed $n-3$ LCPUFA, such as fish and fish products..$^{8,10,33,36,37}$ In a study with adult lactating women in Rio de Janeiro ${ }^{37}$ PUFA contributed with approximately $20 \%$ of total fat intake, and $n-6$ fatty acids were the main PUFA $(>80 \%)$ in the diet. Vegetable oils, mainly soybean oil, were the main sources of $n-6$ $(61 \%)$ and $n-3$ PUFA (52\%). Fish and fish oils intake contributed with only $4 \%$ of $n-3$ PUFA intake. ${ }^{37}$

Data on nutrient intakes in adolescents during pregnancy and lactation are scarcer than those in adult women, with limited information even in industrialized countries. ${ }^{29}$ Recent studies with pregnant ${ }^{27}$ and lactating ${ }^{28}$ adolescents in Rio de Janeiro showed that $n-3, n-6$ and total PUFA intakes were lower than the $\mathrm{AMDR}^{30}$ and the intakes reported for Brazilian lactating women of similar socioeconomic condition, ${ }^{37}$ resulting in higher $n-6 / n-3$ ratio in the diet of adolescents. Foods prepared with soybean oil were consumed by all adolescents, whereas only $10 \%$ of them reported regular intake of fish and fish products (on a weekly or monthly basis), showing a low intake of a major source of $n-3$ LCPUFA. These results are consistent with the findings of other studies with adolescents in Rio de Janeiro, in which relatively high intake of food sources of saturated fat and low intake of food sources of polyunsaturated fat were reported. ${ }^{2,3}$

\section{BIOCHEMICAL INDICES OF PUFA STATUS IN ADOLESCENT AND ADULT BRAZILIAN WOMEN DURING PREGNANCY AND LACTATION}

Studies with adult women have shown that EFA and LCPUFA intake from diet or supplements affects maternal status during pregnancy ${ }^{18,32}$ and lactation. ${ }^{15,19}$ The habitual dietary intake patterns of these fatty acids in both adolescent and adult Brazilian mothers would imply that $n$-3 LCPUFA status in these women might be impaired, especially in adolescents.

According to data from the Brazilian Ministry Information System on Live Births (Sistema de Informações sobre Nascidos Vivos - SINASC), approximately 21\% of all live births in 2005 were from adolescent mothers. ${ }^{a}$ Adolescence is a period characterized by intense anabolism, with increase in body mass, development of inter- nal organs and systems, skeletal and sexual maturation and changes in the amount and distribution of adipose tissue. ${ }^{26}$ When pregnancy and subsequent lactation are superimposed upon adolescence, nutritional risks associated with each condition may be further enhanced.

The biochemical indices of EFA and LCPUFA statuses most commonly used are based on fatty acid composition of plasma ${ }^{12,34}$ and erythrocyte phospholipids. ${ }^{13,35,40}$ Erythrocyte membrane fatty acid composition has been used as a biochemical marker of intake of fatty acids not endogenously synthesized ${ }^{15,32,38}$ and as a biochemical and functional index of EFA and LCPUFA maternal and infant status. ${ }^{13,17,33,35,40}$

In addition to the relative concentration $(\mathrm{g} / 100 \mathrm{~g})$ of individual fatty acids in the erythrocyte membrane, other indices have been proposed and used in different studies to characterize PUFA status: EFA status index (EFASTI; $\left.\left[\Sigma n-3+\sum n-6\right] /\left[\sum n-7+\Sigma n-9\right]\right)$, DHA status indices, and mean melting point (MMP). DHA indices are calculated as $22: 6 n-3 / 22: 5 n-6$ and $22: 5 n-6 / 22: 4 n-6$ ratios. Increased 22:6n-3/22:5n-6 indicates a balance between metabolic equivalents of $n-3$ and $n-6$ LCPUFA, which favors DHA. ${ }^{27,28,40}$ Therefore, the higher this index, the higher the functional DHA status. ${ }^{40}$ On the other hand, increased 22:5n-6/22:4n-6 indicates a balance favoring $n$-6 LCPUFA over DHA, ${ }^{27,28,40}$ and thus the higher this index, the lower the functional DHA status. ${ }^{40}$ The calculation of these indices takes into account the competitive metabolism of different fatty acids series, mainly $n-3$ and $n-6$, as for EFA and DHA indices. The MMP ${ }^{16}$ is also calculated for overall and weighted contribution of different fatty acid families. For instance, competition between PUFA series plays an important role on DHA status since high n-6 PUFA intake may impair DHA status even when individual DHA erythrocyte levels seem adequate. As for MMP, which is an index of membrane "fluidity", high levels are suggestive of PUFA deficiency, since the relative contribution of fatty acids with more unsaturated chains, which have lower melting points, would be diminished in the index calculation. ${ }^{16}$ These indices provide complementary information and are likely to give better estimates of EFA and LCPUFA maternal status than quantitative comparisons of individual fatty acids. Furthermore, they are more useful for comparisons across studies.

There has been a remarkable lack of information on the impact of pregnancy and lactation on EFA and LCPUFA status of adult and adolescent Brazilian women during the reproductive cycle. In order to retrieve references of published papers on fatty acid status in Brazilian pregnant and lactating women, a search was conducted in the ISI Web of Knowledge ${ }^{\mathrm{SM}}$ using the keywords "lactation* AND fatty acid* AND Brazil*" and "gestation* AND fatty acid* AND Brazil*". Eight results

a Ministério da Saúde. Datasus (2005). Sinasc - Sistema de informações sobre nascidos vivos [internet] [cited 2008 Dec 10]. Available from: http://tabnet.datasus.gov.br/cgi/deftohtm.exe?sinasc/cnv/nvuf.def 
were retrieved for each search, but only four were relevant and selected. ${ }^{27,28,33,37}$ Recent studies carried out in Rio de Janeiro have addressed this issue and their results are discussed here. Table 1 shows PUFA status of Brazilian pregnant ${ }^{27,33}$ and lactating ${ }^{28,37}$ adult and adolescent mothers of similar socioeconomic condition using erythrocyte membrane fatty acid composition as a proxy of EFA and LCPUFA statuses.

Pregnant adolescents have significantly lower levels of DHA and total $n-6, n-3$ and LCPUFA than pregnant adults, whereas lactating adolescents have unexpectedly higher levels of EPA, DHA, n3/n6 ratio, and total $n-6, n-3$ and LCPUFA than lactating adults (Table 1). However, there are no differences in EFASTI, 22:6n3/22:5n-6 and 22:5n-6/22:4n-6 between adolescents and adults either pregnant or lactating, despite more inadequate intake of LCPUFA especially of $n-3$ series were seen in adolescents. ${ }^{28,37}$ These results suggest that pregnancy and lactation affect differently PUFA status of adults and adolescents. The apparent inconsistencies between adolescents and adults when comparing individual fatty acids or PUFA status indices, mainly $22: 6 n-3 / 22: 5 n-6$ and $22: 5 n-6 / 22: 4 n-6$, draw attention to the fact that assessment of fatty acid status should not be based solely on measures of individual fatty acids.

Studies with adult women in developed countries show aggravation of EFA and DHA status during pregnancy and recovery during lactation. ${ }^{1,40}$ Similarly, among Brazilian women (Table 1), EFA status improved during lactation in both adolescents and adults, since EFASTI was higher in lactating adolescents (tendency, $p<0.1$ ) and adults $(p<0.001)$ than pregnant women. However, $22: 6 n-3 / 22: 5 n-6$ did not improve during lactation in both Brazilian adolescents and adults, and 22:5n-6 /22:4n-6 improved only in adults (Table 1).

A comparison of EFA and DHA indices of Brazilian mothers with adult mothers in the Netherlands ${ }^{1,40}$ shows that EFASTI values are higher in Brazilian mothers mainly due to the contribution of erythrocyte membrane linoleic acid and AA. A comparison with German mothers ${ }^{5}$ also shows that Brazilian mothers have higher levels of erythrocyte linoleic acid plus AA. However, Brazilian mothers had poorer DHA status, as shown by their lower $22: 6 n-3 / 22: 5 n-6$ and higher $22: 5 n-6 / 22: 4 n-6$ values in the erythrocyte membrane. These findings are consistent with the dietary pattern of Brazilian mothers, with relatively high intake of n-6 PUFA, especially linoleic acid, and low intake of preformed n-3 LCPUFA, especially DHA, compared with mothers in other countries where intake of $n-3$ fatty acids is higher. ${ }^{40,41}$ This dietary pattern might also contribute to explain the non-improvement in 22:6n-3 $/ 22: 5 n-6$ and 22:5n-6/22:4n-6 among Brazilian mothers during the lactation period studied.

Table 1. Essential and LCPUFA status of Brazilian women during the reproductive cycle derived from erythrocyte membrane fatty acids.

\begin{tabular}{|c|c|c|c|c|}
\hline \multirow[b]{2}{*}{ Fatty acid status } & \multicolumn{2}{|c|}{ Pregnant women (38 weeks of gestation) } & \multicolumn{2}{|c|}{ Lactating women (30-120 days postpartum } \\
\hline & $\begin{array}{c}\text { Adults }^{35} \\
(n=30) \\
\text { Mean } \pm \text { SD }\end{array}$ & $\begin{array}{c}\text { Adolescents }^{28} \\
(n=26) \\
\text { Mean } \pm \text { SD }\end{array}$ & $\begin{array}{c}\text { Adults }^{39} \\
(n=24) \\
\text { Mean } \pm \text { SD }\end{array}$ & $\begin{array}{c}\text { Adolescents }^{29} \\
(n=28) \\
\text { Mean } \pm \text { SD }\end{array}$ \\
\hline $18: 2 n-6(g / 100 \mathrm{~g})$ & $9.8 \pm 1.6$ & $9.7 \pm 1.9$ & $9.6 \pm 1.3$ & $9.7 \pm 1.8$ \\
\hline $20: 4 n-6(g / 100 g)$ & $11.4 \pm 2.2$ & $10.9 \pm 2.1$ & $11.5 \pm 1.8$ & $12.1 \pm 1.6^{\mathbf{a}_{1} *}$ \\
\hline Total $n-6$ (g/100 g) & $27.2 \pm 0.2$ & $25.6 \pm 3.7^{\mathbf{b}, *}$ & $25.9 \pm 3.7^{\mathbf{c}_{, *}}$ & $27.7 \pm 2.6^{\mathbf{a}_{1 *}}$ \\
\hline $18: 3 n-3(g / 100 \mathrm{~g})$ & $t r$. & $t r$. & $0.10 \pm 0.02$ & tr. \\
\hline $20: 5 n-3(g / 100 g)$ & tr. & $0.8 \pm 0.8$ & $0.33 \pm 0.18^{\mathbf{c}, *}$ & $0.99 \pm 1.30$ \\
\hline $22: 6 n-3(g / 100 \mathrm{~g})$ & $4.6 \pm 0.48^{\mathbf{d}_{, * * *}}$ & $3.4 \pm 1.5^{\mathbf{b}, * * *}$ & $3.7 \pm 0.46^{\mathbf{c}, *}$ & $4.5 \pm 1.9^{\mathrm{a}_{\text {, } *}}$ \\
\hline Total $n-3$ (g/100 g) & $6.8 \pm 0.54^{\mathbf{d}_{, * * *}}$ & $5.1 \pm 2.2^{\mathbf{b}, * *}$ & $5.6 \pm 0.75^{\mathbf{c}, * * *}$ & $8.6 \pm 2.7^{\mathbf{a}, * * *}$ \\
\hline$n-3 / n-6$ & $0.25 \pm 0.02$ & $0.20 \pm 0.11$ & $0.22 \pm 0.06^{\mathbf{c}, * * *}$ & $0.32 \pm 0.13^{\mathbf{a}, * * *}$ \\
\hline Total LCPUFA (g/100 g) & $23.2 \pm 1.4^{\mathrm{d}, *}$ & $21.0 \pm 2.8^{\mathbf{b}, * * *}$ & $21.8 \pm 3.1^{\mathbf{c}, * * *}$ & $26.5 \pm 3.0^{\mathbf{a}, * * *}$ \\
\hline EFASTI & $2.0 \pm 0.2^{\mathrm{d}, * * *}$ & $2.0 \pm 0.5$ & $2.3 \pm 0.27$ & $2.2 \pm 0.2$ \\
\hline $22: 6 n-3 / 22: 5 n-6$ & $5.8 \pm 1.8$ & $5.4 \pm 3.0$ & $6.5 \pm 1.8$ & $5.9 \pm 4.0$ \\
\hline $22: 5 n-6 / 22: 4 n-6$ & $0.29 \pm 0.09^{\mathbf{d}, *}$ & $0.30 \pm 0.18$ & $0.24 \pm 0.06$ & $0.27 \pm 0.10$ \\
\hline $\mathrm{MMP}\left({ }^{\circ} \mathrm{C}\right)$ & $27.7 \pm 1.3^{\mathbf{d}, * *}$ & $29.3 \pm 1.5^{\mathbf{b}, * *}$ & $29.7 \pm 3.2^{\mathbf{c}, * * *}$ & $24.8 \pm 3.0^{\mathbf{a}, * * *}$ \\
\hline
\end{tabular}

tr., traces; $n-3 / n-6$, ratio between the sum of all $n-3$ and $n-6$ fatty acids; LCPUFA, the sum of all polyunsaturated fatty acids with 20C or more; EFASTI, essential fatty acid status index $[(\Sigma n-6+\Sigma n-3) /(\Sigma n-7+\Sigma n-9)] ; 22: 6 n-3 / 22: 5 n-6$ and 22:5n-6/ 22:4n-6, DHA status indices; MMP, mean melting point.

Comparisons between groups (t-test): ${ }^{\mathbf{a}}$ significantly different from pregnant adolescents; ${ }^{\mathbf{b}}$ significantly different from pregnant adults; ${ }^{\mathbf{c}}$ significantly different from lactating adolescents; ${ }^{\mathbf{d}}$ significantly different from lactating adults;

${ }^{*} p<0.05$

$* * p<0.01$

$* * * p<0.001$ 


\section{MATERNAL-FETAL TRANSFER OF PUFA}

The exponential accretion of LCPUFA in fetal tissues, especially in the brain, which occurs from gestation week 30 to 38 places a high demand for these fatty acids from maternal circulation, ${ }^{14}$ which partially explains the progressive decline in EFA, AA and DHA maternal status towards the end of pregnancy. ${ }^{1,40}$

The availability of LCPUFA during early life affects the quality of growth and the development of visual and cognitive functions. ${ }^{17}$ Several studies have shown that later LCPUFA status in infants is determined by both their status at birth and post-natal diet. ${ }^{13,15,24}$ The evaluation of EFA and LCPUFA status at birth can be an important predictor of future status of fatty acids and development in infants.

Placental transfer of fatty acids is selectively higher for AA and DHA compared to other PUFA. ${ }^{14}$ International studies using erythrocyte membrane ${ }^{35,40}$ and plasma phospholipids ${ }^{9,12}$ in the umbilical cord blood have shown that AA and DHA contents are higher, whereas linoleic acid is lower, in newborn infants than in their mothers, and that full-term infant levels of EFA and LCPUFA are associated to maternal levels. ${ }^{40}$

Another search was conducted in the ISI Web of Knowledge ${ }^{\mathrm{SM}}$ for papers concerning newborn fatty acid status in Brazil (keywords: "newborn AND infant AND fatty acid* AND Brazil*"). Only two relevant results were retrieved and examined. ${ }^{4,33}$

The evaluation of PUFA status of Brazilian mothers and their full-term infants at birth, ${ }^{33}$ as assessed based on fatty acid composition of erythrocyte membrane, is shown in Figure. Neonatal AA was higher $(p<0.01)$ than maternal levels, whereas its precursor linoleic acid was lower $(p<0.01)$ than maternal levels (Figure A), in accordance with international studies. ${ }^{35,40}$ But there was no difference in EFASTI between mothers and newborn infants (Figure B). However, neonates had poorer DHA status than their mothers, as showed by their lower DHA content (Figure A) and lower 22:6n-3/22:5n-6 and higher 22:5n-6/22:4n-6 (Figure B).

The imbalance between low DHA maternal status and the relatively adequate linoleic acid and AA status possibly contributed to low DHA status of Brazilian infants. This hypothesis is consistent with a negative association between neonatal DHA and maternal AA and positive association between neonatal AA and maternal AA and linoleic acid. Also, in neonates, there was a negative correlation between AA and DHA, and in their mothers, there were found negative correlations between linoleic acid and DHA and between AA and DHA. ${ }^{33}$

Furthermore, Brazilian infants had lower 22:6n-3 $/ 22: 5 n-6$ and higher 22:5n-6/22:4n-6 than term infants in the Netherlands, ${ }^{40}$ although individual contents
( $\mathrm{g} / 100 \mathrm{~g}$ total fatty acids) of linoleic acid, AA and DHA in erythrocytes were similar to those described in infants in other countries. ${ }^{35,40}$ Another study ${ }^{4}$ with full-term newborns in Northeast Brazil, in which fatty acid composition of umbilical cord plasma was determined, showed that AA and DHA contents were similar to those seen in newborns in other countries, but biochemical indices were not calculated. These observations support the importance of the evaluation of more integrated biochemical indices together with the fatty acid composition when fatty acid status is compared across different groups.

The results on PUFA status of Brazilian mothers and their newborn infants suggest that the current intake levels of $n$-3 LCPUFA in pregnant women in Brazil may not be sufficient to sustain an increased maternal-fetal transfer of DHA until term.
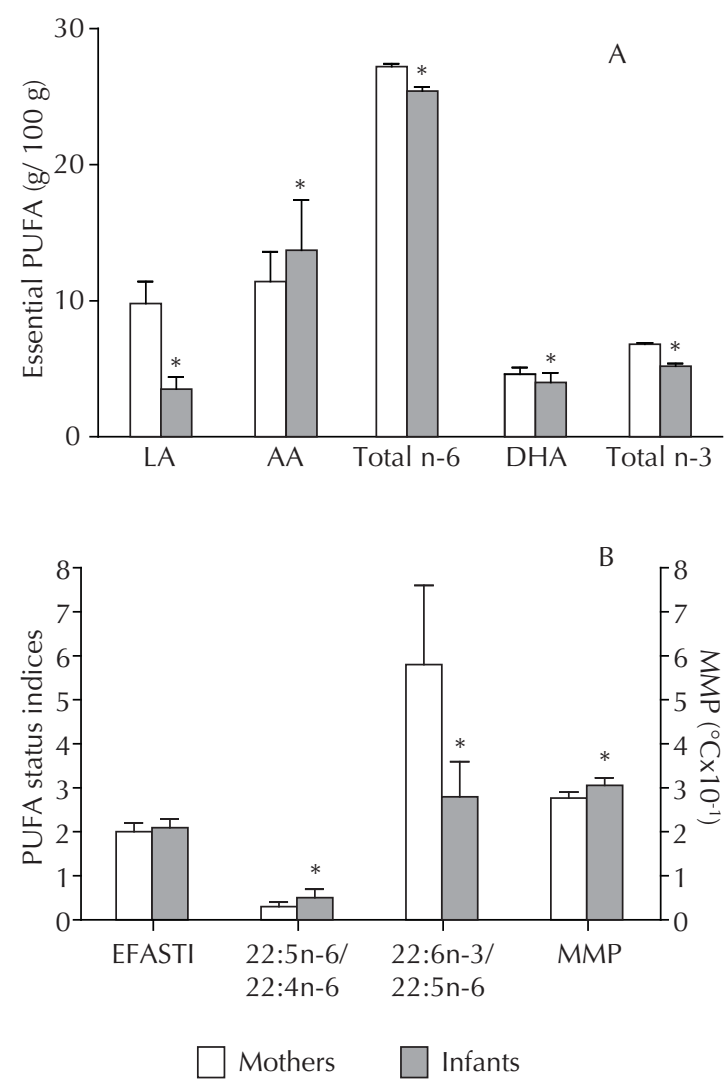

LA: linoleic acid (18:2n-6); AA: arachidonic acid (20:4n-6); DHA: docosahexaenoic acid (22:6n-3); 22:5n-6/22:4n-6 and 22:6n-3/22:5n-6: DHA status indices; EFASTI: EFA status index $[(\Sigma \mathrm{n}-6+\Sigma \mathrm{n}-3) /(\Sigma \mathrm{n}-7+\Sigma \mathrm{n}-9)]$; MMP: mean melting point.

Error bars are standard deviations.

* Significantly different from mothers $(p<0.05)$.

Figure. Essential PUFA (A) and PUFA status indices (B) derived from erythrocyte membrane fatty acids in Brazilian mothers $(n=30)$ and their infants $(n=30)$. 


\section{BREAST MILK LCPUFA OF ADULTS AND ADOLESCENTS IN DIFFERENT REGIONS IN BRAZIL}

Human milk PUFA and LCPUFA contents are highly dependent on maternal habitual intake of dietary sources of these fatty acids. ${ }^{17}$ Endogenous synthesis of LCPUFA from shorter chain PUFA is extremely limited in newborns, and insufficient to maintain an adequate status and sustain adequate development. ${ }^{17,22}$ Breast milk is the only source of essential fatty acids, including AA, EPA and DHA, to breastfed infants. Therefore, infant LCPUFA status is determined by maternal status, and consequently an adequate maternal intake of preformed LCPUFA is required during pregnancy and lactation. ${ }^{17}$

Another search was performed in the ISI Web of Knowledge ${ }^{\mathrm{SM}}$ for papers concerning milk fatty acid composition in Brazil (keywords: "breast milk AND fatty acid" AND Brazil*"; period: years 2000-2007). Only three relevant results were retrieved and examined. ${ }^{10,36,37} \mathrm{~A}$ more recent paper concerning milk fatty acid composition of adolescent mothers ${ }^{28}$ was also reviewed.

Data on milk composition of essential $n-3$ and $n-6$ PUFA of Brazilian lactating women from three different cities ${ }^{10,36,37}$ recently published using modern gas-chromatographic techniques are presented in Table 2. The general pattern of PUFA composition is similar between the three groups of adult women and the group of adolescents. Direct comparisons between the four groups with statistical tests (unpaired t-tests) are limited because data were generated in different laboratories except for comparisons between adults and adolescents in Rio de Janeiro, ${ }^{28,37}$ which are from the same laboratory. Considering the limitation mentioned, comparison between milk of adolescents in Rio de Janeiro and adults in Brasília ${ }^{10}$ and Viçosa ${ }^{36}$ showed that total LCPUFA, AA, EPA and DHA were significantly different $(p<0.0005)$ between adults and adolescents.
However, the comparison of milk composition of adults and adolescents in Rio de Janeiro with similar socioeconomic conditions, showed that the only significant difference was in total LCPUFA $(p<0.0001)$, which was lower in adolescents, and that AA tended $(p=0.054)$ also to be lower. The absence of marked differences in $n-3$ and $n-6$ LCPUFA in breast milk of adults and adolescents in Rio de Janeiro despite lower intake of $n-3$ and $n-6$ fatty acids among adolescents was unexpected. It is possible that transfer of EFA and LCPUFA to mammary glands in adolescents is preferred than to maternal tissues and as efficient as in adult women. These results are consistent with the known modulation of breast milk fatty acid composition by maternal hormones. ${ }^{31}$

In general, fatty acid composition in human milk of Brazilian women is similar to that of women in other countries. ${ }^{21}$ But milk DHA is lower in most studies with Brazilian women ${ }^{28,36,37}$ when compared to average international data. ${ }^{6}$ These results are consistent with low intake of dietary sources of $n-3$ LCPUFA seen in Brazilian lactating women and their DHA status evaluated through several indices. ${ }^{28,37}$

Breast milk is the only source of LCPUFA to the developing newborn, thus maintenance and recovery of infant status is strictly dependent on an adequate supply of these fatty acids. When infants are born with inadequate DHA status, and EPA and DHA are low in breast milk, as it seems to be the case in Brazil, ${ }^{28,33,37}$ LCPUFA status may not be recovered. This inadequacy may have longterm developmental consequences as has been shown in studies with infants in other countries. ${ }^{17,39}$ However, the impact of inadequate supply of LCPUFA on infant development has not been evaluated in Brazil.

A recent study in Brazilian Northeastern infants showed that, after controlling for confounders, full breastfeeding for one month showed a small but significant benefit for mental development at twelve months. ${ }^{11}$ Although

Table 2. Essential fatty acids and LCPUFA in breast milk of adult and adolescent Brazilian women.

\begin{tabular}{|c|c|c|c|c|}
\hline \multirow[b]{2}{*}{ Essential $n-3$ and $n-6$ PUFA } & \multicolumn{3}{|c|}{ Adults } & \multirow{2}{*}{$\begin{array}{c}\text { Adolescents } \\
\text { Rio de Janeiro, } \mathrm{R}^{29} \\
(\mathrm{n}=28) \\
\text { Mean } \pm \mathrm{SD}\end{array}$} \\
\hline & $\begin{array}{c}\text { Rio de Janeiro, RJ }{ }^{39} \\
(\mathrm{n}=33) \\
\text { Mean } \pm \mathrm{SD}\end{array}$ & $\begin{array}{c}\text { Brasília, } \text { DF }^{9} \\
(n=77) \\
\text { Mean } \pm \text { SD }\end{array}$ & $\begin{array}{c}\text { Viçosa, } M^{38} \\
(n=80) \\
\text { Mean } \pm S D\end{array}$ & \\
\hline $18: 2 n-6(g / 100 \mathrm{~g})$ & $16.6 \pm 3.9$ & $20.6 \pm 4.9$ & $20.3 \pm 6.5$ & $17.3 \pm 4.8$ \\
\hline $20: 4 n-6(g / 100 \mathrm{~g})$ & $0.47 \pm 0.13$ & $0.71 \pm 0.18$ & $0.53 \pm 0.14$ & $0.40 \pm 0.15$ \\
\hline Total n-6 (g/100 g) & $17.9 \pm 3.95$ & $22.4 \pm 9.7$ & $21.8 \pm 6.7$ & $18.3 \pm 5.3$ \\
\hline $18: 3 n-3(g / 100 \mathrm{~g})$ & $1.16 \pm 0.31$ & $1.93 \pm 1.31$ & $1.43 \pm 0.66$ & $1.08 \pm 0.54$ \\
\hline $20: 5 n-3(g / 100 \mathrm{~g})$ & $0.07 \pm 0.05$ & $0.16 \pm 0.08$ & tr. & $0.05 \pm 0.01$ \\
\hline $22: 6 n-3(g / 100 \mathrm{~g})$ & $0.22 \pm 0.10$ & $0.34 \pm 0.19$ & $0.14 \pm 0.05$ & $0.20 \pm 0.10$ \\
\hline Total $n-3$ (g/100 g) & $1.61 \pm 0.39$ & $2.62 \pm 1.20$ & $1.6 \pm 0.67$ & $1.70 \pm 0.54$ \\
\hline$n-3 / n-6$ & $0.091 \pm 0.018$ & $0.14 \pm 0.02$ & $0.07 \pm 0.02$ & $0.09 \pm 0.01$ \\
\hline Total LCPUFA (g/100 g) & $1.88 \pm 0.47$ & $2.44 \pm 1.28$ & $1.56 \pm 0.48$ & $1.17 \pm 0.30$ \\
\hline
\end{tabular}

PUFA, polyunsaturated fatty acids; tr., traces; $n-3 / n-6$, ratio between the sum of all $n-3$ and $n-6$ fatty acids; LCPUFA, the sum of all polyunsaturated fatty acids with $20 \mathrm{C}$ or more. 
nutritional components of breast milk involved in this slight but positive effect of breastfeeding were not evaluated, milk LCPUFA might have contributed to this outcome. It could be hypothesized that if higher levels of milk AA and especially DHA were present in the breast milk of Brazilian women, more marked benefits would be seen.

\section{CONCLUSIONS}

Considering food consumption data in the general population ${ }^{23}$ and in pregnant and lactating women in limited studies ${ }^{3,8,10,28,33,36,37}$ in Brazil, and current dietary recommendations and guidelines from international expert groups, ${ }^{22,30}$ it could be hypothesized that dietary intake of $n-3$ LCPUFA is inadequate, especially in pregnant and lactating women. This hypothesis requires to be directly tested in population-based studies designed to specifically measure PUFA and LCPUFA intake and to allow comparisons with reference data through appropriate statistics.

Published data on PUFA and LCPUFA status of pregnant and lactating Brazilian women are consistent with data on dietary intake of these fatty acids, and point to evidence of inadequacy of DHA status evaluated through several biochemical markers, including milk composition, across the reproductive cycle. Inadequate LCPUFA status of women during the reproductive cycle might have negative consequences for the developing infant as well as for the mother. If maternal status is depleted after the cycle of pregnancy and lactation, and is not recovered through appropriate dietary intake, it could be speculated that maternal status would be further depleted in a subsequent reproductive cycle. It is imperative that cohort studies are specifically designed to measure post-partum and post-lactation recovery of maternal status, evaluated through integrative biochemical indices, in Brazilian women with current habitual intake of sources of PUFA and LCPUFA.

Neural function of Brazilian newborns and breastfed and non-breastfed infants should be evaluated in systematic studies in order to determine the developmental risk potentially caused by inadequate maternal DHA intake. It should also be determined whether proper maternal nutrition would result in adequate statuses in mothers and infants, and how valid are international reference intakes of LCPUFA for Brazilian mothers. 


\section{REFERENCES}

1. Al MDM, Van Houwelingen AC, Hornstra G. Longchain polyunsaturated fatty acids, pregnancy, and pregnancy outcome. Am J Clin Nutr. 2000;71(Supl 1):S285-91.

2. Andrade RG, Pereira RA, Sichieri R. Consumo alimentar de adolescentes com e sem sobrepeso do município do Rio de Janeiro. Cad Saude Publica. 2003;19(5):1485-95. DOI: 10.1590/S0102$311 \times 2003000500027$

3. Barros DC, Pereira RA, Gama SGN, Leal MC. O consumo alimentar de gestantes adolescentes no município do Rio de Janeiro. Cad Saude Publica. 2004;20(Supl 1):S121-9.

4. Barros MFA, Leger CL, Lira PIC, Lima MC, Carbonneau MA, Bernard Descomps B, et al. Cord blood essential fatty acid and alpha-tocopherol in full-term newborns in a Northeast Brazil area. Int J Vitamin Nutr Res. 2002;72(3):155-60.

5. Böhles H, Arndt S, Ohlenschläger U, Beeg T, Gebhardt B, Sewell AC. Maternal plasma homocysteine, placenta status and docosahexaenoic acid concentration in erythrocytes phospholipids of the newborn. Eur J Pediatr. 1999;158(3):243-6. DOI: 10.1007/ s004310051059

6. Brenna JT, Varamini B, Jensen RG, Diersen-Schade DA, Boettcher JA, Arterburn LN. Docosahexaenoic and arachidonic acid concentrations in human breast milk worldwide. Am / Clin Nutr. 2007;85(6):1457-64.

7. Burdge GC, Calder PC. Dietary $\alpha$-linolenic acid and health-related outcomes: a metabolic perspective. Nutr Res Rev. 2006;19(1):26-52. DOI: 10.1079/ NRR2005113

8. Castro MBT, Kac G, Sichieri R. Padrão de consumo alimentar em mulheres no pós-parto atendidas em um centro municipal de saúde do Rio de Janeiro, Brasil. Cad Saude Publica. 2006;22(6):1159-70. DOI: 10.1590/S0102-311X2006000600005

9. Crawford MA, Costeloe K, Ghebremeskel K, Phylactos A, Skirvin L, Stacey F. Are deficits of arachidonic and docosahexaenoic acids responsible for the neural and vascular complications of preterm babies? Am / Clin Nutr. 1997;66(Supl 4):S1032-41.

10. Cunha J, Costa TH Ito MK. Influences of maternal dietary intake and suckling on breast milk lipid and fatty acid composition in low-income women from Brasília, Brazil. Early Hum Dev. 2005;81(3):303-11. DOI:_10.1016/j.earlhumdev.2004.08.004

11. Eickman SH, Lira PI, Lima MC, Coutinho SB, Teixeira $\mathrm{ML}$, Ashworth A. Breast feeding and mental and motor development at 12 months in a low-income population in northeast Brazil. Paediatr Perinat Epidemiol. 2007;21(2):129-37. DOI: 10.1111/j.13653016.2007.00795.x

12. Elias SL, Innis SM. Infant plasma trans, $n-6$, and $n-3$ fatty acids and conjugated linoleic acids are related to maternal plasma fatty acids, length of gestation, and birth weight and length. Am J Clin Nutr. 2001;73(4):807-14.
13. Guesnet $P$, Pugo-Gunsam $P$, Maurage $C$, Pinault M, Giraudeau B, Alessandri JM, et al. Blood lipid concentrations of docosahexaenoic and arachidonic acids at birth determine their relative postnatal changes in term infants fed breast milk or formula. Am J Clin Nutr. 1999;70(2):292-8.

14. Haggarty P. Placental regulation of fatty acid delivery and its effect on fetal growth - a review. Placenta. 2002;23 (Suppl A):S28-38.

15. Henderson RA, Jensen RG, Lammi-Keefe CJ, Ferris AM, Dardick KR. Effect of fish oil on the fatty acid composition of human milk and maternal and infant erythrocytes. Lipids. 1992;27(11):863-9. DOI: 10.1007/BF02535865

16. Holman RT, Johnson SB, Ogburn PL. Deficiency of essential fatty acids and membrane fluidity during pregnancy and lactation. Proc Natl Acad Sci USA. 1991;88(11):4835-9.

17. Innis SM. Human milk: maternal dietary lipids and infant development. Proc Nutr Soc. 2007;66(3):397404. DOI: $10.1017 /$ S0029665107005666

18. Innis SM, Elias SL. Intakes of essential $n-6$ and $n-3$ polyunsaturated fatty acids among pregnant Canadian women. Am J Clin Nutr. 2003;77(2):473-8.

19. Jensen CL, Maude M, Anderson RE, Heird W. Effect of docosahexaenoic acid supplementation of lactating women on the fatty acid composition of breast milk lipids and maternal and infant plasma phospholipids. Am J Clin Nutr. 2000;71(Supl 1):S292-9.

20. Jensen CL. Effects of $n-3$ fatty acids during pregnancy and lactation. Am J Clin Nutr. 2006;83(6 Suppl):S1452-7.

21. Jensen RG. Lipids in human milk. Lipids. 1999;34(12):1243-71. DOI: 10.1007/s11745-9990477-2

22. Koletzko B, Cetin I, Brenna JT, Perinatal Lipid Intake Working Group, Child Health Foundation, Diabetic Pregnancy Study Group, et al. Dietary fat intakes for pregnant and lactating women. Br J Nutr. 2007;98(5):873-7. DOI: 10.1017/S0007114507764747

23. Levy-Costa RB, Sichieri R, Pontes NS, Monteiro CA. Disponibilidade domiciliar de alimentos no Brasil: distribuição e evolução (1974-2003). Rev Saude Publica. 2005;39(4):1-10. DOI: 10.1590/S003489102005000400003

24. Makrides M, Neumann MA, Gibson, RA. Effect of maternal docosahexaenoic acid (DHA) supplementation on breast milk composition. Eur J Clin Nutr. 1996;50(6):352-7.

25. Martino R, Trugo LC, Cyrino JEP, Portz L. Use of white fat as a replacement for squid liver oil in practical diets for Surubim Pseudoplatystoma coruscans. I World Aquac Soc. 2003;34(2):192-202. DOI: 10.1111/ j.1749-7345.2003.tb00056.x

26. Mascarenhas MR, Zemel BS, Tershakovec AM, Stallings VA. Adolescence. In: Bowman BA, Russell RM. Present knowledge in nutrition. 8. ed. Washington, DC: ILSI; 2001. p.426-38. 
27. Meneses F, Ney JG, Torres AG, Trugo NMF. Erythrocyte membrane and plasma non-esterified $n-3$ and $n-6$ polyunsaturated fatty acids of pregnant and nonpregnant Brazilian adolescents. Prostaglandins Leukot Essent Fatty Acids 2009; in press DOI: 10.1016/j. plefa.2008.12

28. Meneses F, Torres AG, Trugo NMF. Essential and longchain polyunsaturated fatty acid status and fatty acid composition of breast milk of lactating adolescents. Br J Nutr. 2008;100(5):1029-37. DOI: 10.1017/ S0007114508945177

29. Moran VH. A systematic review of dietary assessments of pregnant adolescents in industrialized countries. Br J Nutr. 2007;97(3):411-25. DOI: 10.1017/ S0007114507381373

30. National Academy of Sciences. Institute of Medicine. Dietary reference intakes for energy, carbohydrate, fiber, fat, fatty acids, cholesterol, protein, and amino acids. Washington, DC; 2005.

31. Neville MC, Picciano MF. Regulation of milk lipid secretion and composition. Annu Rev Nutr. 1997;17:159-83. DOI: 10.1146/annurev. nutr.17.1.159

32. Parra MS, Schnaas L, Meydani M, Perroni E, Martinez S, Romieu I. Erythrocyte cell membrane phospholipid levels compared against reported dietary intakes of polyunsaturated fatty acids in pregnant Mexican women. Public Health Nutr. 2002;5(6A):931-7. DOI: 10.1079/PHN2002381

33. Pontes PV, Torres AG, Trugo NMF, Fonseca VM, Sichieri R. n-6 and n-3 Long-chain polyunsaturated fatty acids in the erythrocyte membrane of Brazilian preterm and term neonates and their mothers at delivery. Prostaglandins Leukot Essent Fatty Acids. 2006;74(2):117-23. DOI: 10.1016/j. plefa.2005.11.002
34. Rump P, Mensink RP, Kester ADM, Hornstra G. Essential fatty acid composition of plasma phospholipids and birth weight: a study in term neonates. Am J Clin Nutr. 2001;73(4):797-806.

35. Ruyle M, Connor WE, Anderson GJ, Lowensohn RI. Placental transfer of essential fatty acids in humans: venous-arterial difference for docosahexaenoic acid in fetal umbilical erythrocytes. Proc Natl Acad Sci USA. 1990;87(20):7902-6. DOI: 10.1073/pnas.87.20.7902

36. Silva MHL, Silva MTC, Brandão SCC, Gomes JC, Peternelli LA, Franceschini SCC. Fatty acid composition of mature breast milk in Brazilian women. Food Chem. 2005;93(2):297-303. DOI: 10.1016/j. foodchem.2004.09.026

37. Torres AG, Ney JG, Meneses F, Trugo NMF. Polyunsaturated fatty acids and conjugated linoleic acid isomers in breast milk are associated with plasma non-esterified and erythrocyte membrane fatty acid composition in lactating women. Br J Nutr. 2006;95(3):517-24. DOI: 10.1079/BJN20051645

38. Trugo NMF, Torres AG. Indicadores bioquímicos na avaliação do estado nutricional. In: Kac G, Sichieri R, Gigante, DP. Epidemiologia nutricional. Rio de Janeiro: Fiocruz/ Atheneu; 2007. p.127-47.

39. Uauy R, Dangour AD. Nutrition in brain development and aging role of essential fatty acids. Nutr Rev. 2006;64(5 Pt 2):S24-33. DOI: 10.1301/nr.2006.may. S24-S33

40. Vlaadingerbroek H, Hornstra G. Essential fatty acids in erythrocyte phospholipids during pregnancy and at delivery in mothers and their neonates: comparison with plasma phospholipids. Prostaglandins Leukot Essent Fatty Acids. 2004;71(6):363-74. DOI: 10.1016/j. plefa.2004.07.002

41. Zoeet Nederland. Resultaten van de Voedselconsumptiepeiling 1997-1998. Den Haag: Voedingscentrum; 1998.

Research funded by Conselho Nacional de Desenvolvimento Científico e Tecnológico (CNPq; process n. ${ }^{\circ}$ 481373/2007-15), Fundação de Amparo à Pesquisa do Estado do Rio de Janeiro (FAPERJ); process n. ${ }^{\circ}$ E-26/111.454/2008) and Coordenação de Aperfeiçoamento de Pessoal de Nível Superior (CAPES).

NMF Trugo was supported by CNPq (research productivity scholarship). 